\title{
The South-American distribution and southernmost record of Biomphalaria peregrina - a potential intermediate host of schistosomiasis
}

\author{
Alejandra Rumi ${ }^{\text {Corresp., }}$ 1,2 ， Roberto Eugenio Vogler ${ }^{1,2,3}$ ， Ariel Anibal Beltramino ${ }^{1,2,4}$ \\ 1 División Zoología Invertebrados, Facultad de Ciencias Naturales y Museo, Universidad Nacional de La Plata, La Plata, Buenos Aires, Argentina \\ 2 Consejo Nacional de Investigaciones Científicas y Técnicas, CABA, Argentina \\ 3 Instituto de Biología Subtropical, Universidad Nacional de Misiones- Consejo Nacional de Investigaciones Científicas y Técnicas (CONICET), Posadas, \\ Misiones, Argentina \\ 4 Departamento de Biología, Facultad de Ciencias Exactas, Químicas y Naturales, Universidad Nacional de Misiones, Posadas, Misiones, Argentina \\ Corresponding Author: Alejandra Rumi \\ Email address: alerumi@fcnym.unlp.edu.ar
}

Schistosomiasis remains a major parasitic disease, endemic in large parts of South America. Five neotropical species of Biomphalaria have been found to act as intermediate hosts of Schistosoma mansoni in natural populations, while others have been shown to be susceptible in experimental infections, although not found infected in the field. Among these potential intermediate hosts, Biomphalaria peregrina represents the most widespread species in South America, with confirmed occurrence records from Venezuela to northern Patagonia. In this study, we report the southernmost record for the species at the Pinturas River, in southern Patagonia, which finding implies a southward reassessment of the limit for the known species of this genus. The identities of the individuals from this population were confirmed through morphological examination, and by means of two mitochondrial genes, cytochrome oxidase subunit I (COI) and 16S-rRNA. With both markers, phylogenetic analyses were conducted in order to compare the genetic background of individuals from the Pinturas River with previously genetically characterized strains of B. peregrina from various South American locations. In addition, we produced a potential distribution model of B. peregrina in South America and identified the environmental variables that best predict that distribution. The model was estimated through a maximum entropy algorithm and run with occurrence points obtained from several sources, including the scientific literature and international databases, along with climatic and hydrographic variables. Different phylogenetic analyses with either the COI or 16S-rRNA sequences did not conflict, but rather gave very similar topological organizations. Two major groups were identified, with sequences from the Pinturas River grouping together with haplotypes from subtropical and temperate regions. The model developed had a satisfactory performance for the study area. We observed that the areas 
with higher habitat suitability were found to be mainly linked to subtropical and temperate regions of South America between $15^{\circ}$ and $45^{\circ}$ south latitude, with different moderateand low-suitability areas outside this range. We also identified the coldest temperatures as the main predictors of the potential distribution of this snail. Susceptibility surveys would be required to evaluate if southern populations of $B$. peregrina still retain their potential as intermediate hosts of S. mansoni. 
1 The South-American distribution and southernmost record of Biomphalaria peregrina - a

2 potential intermediate host of schistosomiasis

3

4 Alejandra Rumi ${ }^{1,2, *}$, Roberto Eugenio Vogler ${ }^{1,2,3}$ and Ariel Aníbal Beltramino ${ }^{1,2,4}$

5

6 'División Zoología Invertebrados, Facultad de Ciencias Naturales y Museo, Universidad

7 Nacional de La Plata, La Plata, Buenos Aires, Argentina

$8{ }^{2}$ Consejo Nacional de Investigaciones Científicas y Técnicas (CONICET), Argentina

9 Instituto de Biología Subtropical, Universidad Nacional de Misiones - Consejo Nacional de

10 Investigaciones Científicas y Técnicas (CONICET), Posadas, Misiones, Argentina

$11{ }^{4}$ Departamento de Biología, Facultad de Ciencias Exactas, Químicas y Naturales, Universidad

12 Nacional de Misiones, Posadas, Misiones, Argentina

13

$14 *$ Corresponding author:

15 Alejandra Rumi ${ }^{1}$

16 Paseo del Bosque s/n, La Plata, Buenos Aires, B1900BWF, Argentina

17 Email address: alerumi@,fcnym.unlp.edu.ar

18 Short title: Biomphalaria peregrina, potential distribution and southernmost record 


\section{ABSTRACT}

Schistosomiasis remains a major parasitic disease, endemic in large parts of South America. Five neotropical species of Biomphalaria have been found to act as intermediate hosts of Schistosoma mansoni in natural populations, while others have been shown to be susceptible in experimental infections, although not found infected in the field. Among these potential intermediate hosts, Biomphalaria peregrina represents the most widespread species in South America, with confirmed occurrence records from Venezuela to northern Patagonia. In this study, we report the southernmost record for the species at the Pinturas River, in southern Patagonia, which finding implies a southward reassessment of the limit for the known species of this genus. The identities of the individuals from this population were confirmed through morphological examination, and by means of two mitochondrial genes, cytochrome oxidase subunit I (COI) and 16S-rRNA. With both markers, phylogenetic analyses were conducted in order to compare the genetic background of individuals from the Pinturas River with previously genetically characterized strains of $B$. peregrina from various South American locations. In addition, we produced a potential distribution model of $B$. peregrina in South America and identified the environmental variables that best predict that distribution. The model was estimated through a maximum entropy algorithm and run with occurrence points obtained from several sources, including the scientific literature and international databases, along with climatic and hydrographic variables. Different phylogenetic analyses with either the COI or $16 S-r R N A$ sequences did not conflict, but rather gave very similar topological organizations. Two major groups were identified, with sequences from the Pinturas River grouping together with haplotypes from subtropical and temperate regions. The model developed had a satisfactory performance for the study area. We observed that the areas with higher habitat suitability were found to be mainly linked to subtropical and temperate regions of South America between $15^{\circ}$ and $45^{\circ}$ south latitude, with different moderate- and low-suitability areas outside this range. We also identified the coldest temperatures as the main predictors of the potential distribution of this snail. Susceptibility surveys would be required to evaluate if southern populations of $B$. peregrina still retain their potential as intermediate hosts of $S$. mansoni. 


\section{INTRODUCTION}

Schistosomiasis is an acute and chronic parasitic disease that affects at least 258 million people worldwide. Seventy-eight countries are considered endemic for schistosomiasis, with the populations of 52 countries requiring preventive chemotherapy (World Health Organization, 2015). There are two major forms of schistosomiasis -intestinal and urogenital- caused by five main species of trematodes, and the disease is frequent in tropical and subtropical regions, particularly in poor communities (World Health Organization, 2015). In the Americas, the only species present is Schistosoma mansoni (Sambon, 1907) (Digenea); which species is associated with intestinal schistosomiasisis, and is transmitted by the freshwater snails of the genus Biomphalaria Preston, 1910; e.g. Biomphalaria glabrata (Say, 1818), Biomphalaria tenagophila (d'Orbigny, 1835), and Biomphalaria straminea (Dunker, 1848). Other snail species, such as Biomphalaria peregrina (d'Orbigny 1835), have been infected experimentally and are thus considered as potential hosts of S. mansoni (Paraense \& Côrrea, 1973).

In the Americas, schistosomiasis currently occurs in Brazil, Venezuela, Surinam, Puerto

Rico, the Dominican Republic, and on several islands of the Lesser Antilles, with recent evidence indicating a spread from northeastern Brazil southward (Spatz et al., 2000; Kloos et al., 2008; Noya et al., 2015). An expansion of the current disease-distribution area can be expected, since the geographical range of snails that can act as intermedial hosts (IHs) is wider than that of the pathogen (Pan American Health Organization, 2010). The southern area with the highest risk of establishing an endemic and a new focus of disease is located in the northeast of Argentina (the NEA Region), where the majority of the Biomphalaria species inhabit the major rivers of the Del-Plata basin. Five of those species are listed as potential IHs of schistosomiasis: $B$. tenagophila, B. straminea, B. peregrina, B. orbignyi Paraense, 1975, and B. oligoza Paraense, 1974 (Rumi, 1991; Rumi \& Vogler, 2014).

The identification and recognition of Biomphalaria species thus far has mainly relied on features of shell morphology, radula, jaw and the reproductive system ( $c f$. Paraense, 1966, 1975a, 2003; Rumi, 1991). Character similarity among the species, however, has in fact hampered classification, as the case of B. peregrina, B. orbignyi and B. oligoza found in Argentina whose morphological similarities difficult correct identification (Paraense, 1988; Spatz et al., 2000; Vidigal et al., 2000a; Estrada et al., 2006). Within the historical context, several of the South-American species were described in genera of doubtful taxonomic position, 
as the example of Taphius Adams \& Adams, 1855; Biomphalaria Preston, 1910; Tropicorbis Brown \& Pilsbry, 1914; Platytaphius Pilsbry, 1924; and Australorbis Pilsbry, 1934. In addition, the original diagnoses were mostly made based only on shell characters. Both situations facilitated the generation of species of doubtful validity. Subsequently, the anatomical evidence has demonstrated that no differences really existed between the genera and the various taxa all belonging to the same genus (Paraense, 1958). Although the oldest name was Taphius, in 1965 the International Committee of Zoological Nomenclature imposed the sole name Biomphalaria, considering that one to be the most widespread in the world (Barbosa et al., 1961; Paraense, 2008). More recently, though, difficulties concerning morphological identification have been overcome through the use of molecular-genetic techniques that have contributed to delimiting species, mainly those occurring in the Neotropics (e.g. Caldeira et al., 1998; Vidigal et al., 1998, 2004; Spatz et al., 2000).

Among the Biomphalaria species in South America, B. peregrina exhibits one of the most widespread distributions -and one involving a great diversity of hydrologic systems- with that species thus far having been recorded from Venezuela to northern Patagonia, Argentina (Paraense, 1966, 2003, 2004; Rumi, 1991; Spatz et al., 2000; Núñez et al., 2010; Standley et al., 2011). In the study reported here, the presence of B. peregrina in southern Patagonia is now documented for the first time, that location being the southernmost record for the species -and the genus as well- worldwide. In order to confirm the identity of this most southerly population, we assessed the main conchological and anatomical diagnostic characters (e.g. shell, genitalia, and radula) and obtained DNA sequences of the mitochondrial cytochrome oxidase subunit I $(C O I)$ and the 16S-rRNA genes. Based on both markers, we compared the genetic background of individuals from the Pinturas River with previously genetically characterized strains of $B$. peregrina from various South American locations and examined the intra-specific phylogenetic position of the recently discovered population. In addition, upon consideration that B. peregrina represents a potential host for schistosomiasis, we produced a predictive model of the species's spatial distribution in South America and identified the environmental variables that best predict its location. The resulting model indicating the likely whereabouts of that potential host will hopefully provide further guidance for future efforts aimed at schistosomiasis surveillance and control. 
110

111

112

113

114

115

116

117

118

119

120

121

122

123

124

125

126

127

128

129

130

131

132

133

134

135

136

137

138

139

140

\section{MATERIALS AND METHODS}

The material analyzed (19 specimens) came from the Pinturas River, Santa Cruz province, Argentina (Gatherer: Hugo Merlo Álvarez, col. Date: 15-XI-2013, geographical coordinates: $46^{\circ} 50^{\prime} 6^{\prime} \mathrm{S} ; 7^{\circ} 27^{\prime} 38^{\prime \prime} \mathrm{W} ; 355 \mathrm{~m}$ above sea level). The specimens studied were deposited in the malacological collections at the Museo de La Plata (DZI-MLP-Ma), Buenos Aires province (MLP-Ma $\left.\mathrm{N}^{\circ} 14186\right)$.

\section{Morphological examination}

The adult specimens ( $\mathrm{n}=12$; MLP-Ma $\mathrm{N}^{\circ} 14186 / 1$ to $14186 / 12$ ) were analyzed according to Paraense \& Deslandes (1956), Paraense (1966, 1974, 1975a,b) and Rumi (1991). The morphology of the shell, the radula, and the reproductive system were analyzed. The soft parts were separated from the shell for subsequent processing and fixed in Railliet-Henry $-93 \%$ $(\mathrm{v} / \mathrm{v})$ distilled water, 2\% (v/v) glacial acetic acid, 5\% (v/v) formaldehyde, and $6 \mathrm{~g}$ sodium chloride per liter- or $90 \%$ (v/v) aqueous alcohol. Shell measurements (maximum and minimum diameter and height) were obtained with a Mitutoyo digital calipter. The dissection was done under a stereoscopic binocular microscope (LEICA MZ6) (individuals MLP-Ma $\mathrm{N}^{\circ} 14186 / 1$ to 14186/8).

The radula and jaw were cleaned following a modification of the non-destructive method described by Holznagel (1998) and Vogler et al. (2016): the structures were separated from the mass of tissue and placed in 1.5-ml microtubes containing $500 \mu 1 \mathrm{NET}$ buffer $(1 \mathrm{ml} 1 \mathrm{M}$ Tris $\mathrm{pH}$ 8.0, $2 \mathrm{ml} \mathrm{0.5} \mathrm{M} \mathrm{ethylenediaminetetraacetic} \mathrm{acid,} 1 \mathrm{ml} 5 \mathrm{M} \mathrm{NaCl}, 20 \mathrm{ml} \mathrm{10 \%}$ [w/v] sodium dodecyl sulfate, $76 \mathrm{ml}$ water) and $10 \mu \mathrm{l}$ of Proteinase K $(20 \mathrm{mg} / \mathrm{ml})$ were added. The samples were then incubated at $37{ }^{\circ} \mathrm{C}$ with a subsequent renewal of the NET buffer and Proteinase $\mathrm{K}$ to verify the absence of tissue. After two washes with distilled water, 25\% (v/v) aqueous ethanol was added for preservation. Finally the radula and jaw were examined by scanning electron microscopy (JEOL 6360) in the Museum of La Plata (individuals MLP-Ma N ${ }^{\circ}$ 14186/1, MLP$\mathrm{Ma} \mathrm{N}^{\circ}$ 14186/2, MLP-Ma N 14186/4 and MLP-Ma $\mathrm{N}^{\circ}$ 14186/6). The radular formula gives the number of teeth per row: [(number of left teeth) + (number of central teeth) + (number of right teeth)] plus the number of transverse rows (Paraense \& Deslandes, 1956).

$D N A$ extraction, polymerase chain reaction (PCR) and DNA sequencing 
Total genomic DNA was extracted from the foot muscle of five individual snails (MLP-

$142 \mathrm{Ma} \mathrm{N}^{\circ} 14186 / 1$ to $14186 / 5$ ) through the use of the DNeasy Blood \& Tissue kit (Qiagen, 143 Valencia, CA) according to the manufacturer's protocol. Partial sequences of the mitochondrial 144 cytochrome oxidase subunit I (COI) and the $16 S$-rRNA genes were amplified by means of the 145 primers LCO1490 (5'-GGT CAA CAA ATC ATA AAG ATA TTG G-3') and HCO2198 (5'146 TAA ACT TCA GGG TGA CCA AAA AAT CA-3') for COI (Folmer et al., 1994), and 16SF147104 (5'-GAC TGT GCT AAG GTA GCA TAA T-3') and 16SR-472 (5'-TCG TAG TCC AAC 148 ATC GAG GTC A-3') for 16S-rRNA (Ramírez \& Ramírez, 2010). The amplification of the COI 149 region was conducted following Vogler et al. (2014). The amplification of $16 S-r R N A$ was 150 performed in a total volume of $30 \mu \mathrm{l}$ containing $30-50 \mathrm{ng}$ of template DNA, $0.2 \mu \mathrm{M}$ of each 151 primer, 1X PCR green buffer, $0.2 \mathrm{mM}$ dNTPs, and 1 U Dream Taq DNA Polymerase (Thermo 152 Scientific). The thermocycling profile was 35 cycles of $30 \mathrm{~s}$ at $94{ }^{\circ} \mathrm{C}, 30 \mathrm{~s}$ at $48{ }^{\circ} \mathrm{C}, 1 \mathrm{~min}$ at 72 $153{ }^{\circ} \mathrm{C}$ followed by a final extension of $1 \mathrm{~min}$ at $72{ }^{\circ} \mathrm{C}$. The amplifications were run on a T18 154 thermocycler (Ivema Desarrollos). The PCR products were purified by means of a ADN 155 PuriPrep-GP kit (InBio-Highway, Tandil, Buenos Aires). After purification, both DNA strands 156 for each gene were then directly cycle-sequenced (Macrogen Inc., Seoul, Korea). The resulting 157 sequences were trimmed to remove the primers, and the consensus sequences between forward 158 and reverse sequencing were obtained by means of the BioEdit 7.2.5 software (Hall, 1999).

159

160

161

162

163

164

165

166

167

168

169

170

171

\section{Phylogenetic analysis}

The consensus sequences of the individuals were compared to reference sequences in GenBank through the use of the BLASTN algorithm (Altschul et al., 1990) to identify similar sequences in order to confirm the morphology-based identification. Subsequently, phylogenetic analyses were conducted to explore the possible intra-specific phylogenetic relationships of the genetic sequences from the southernmost individuals from the Pinturas River to those of other $B$. peregrina individuals from various locations available in GenBank (Table 1). Sequences of other similar species to $B$. peregrina were not used in the analysis. The phylogenetic analyses were carried out separately for each mitochondrial region as follows: the sequence alignment was performed with Clustal X 2.1 (Larkin et al., 2007), and optimized by visual inspection. The total lengths of the matrices analyzed were $546 \mathrm{bp}$ for the COI gene, and $269 \mathrm{bp}$ for the $16 S-r R N A$ locus. The data were subjected to four different phylogenetic analyses by the methods of 
172 neighbor joining (NJ), maximum parsimony (MP), maximum likelihood (ML), and Bayesian 173 inference (BI). The NJ analysis was conducted with MEGA 6.06 (Tamura et al., 2013) through 174 the use of the Kimura's two-parameter (K2P) substitution model. The MP and ML analyses were 175 carried out with PAUP*4.0b10 (Swofford, 2002). The MP was conducted by means of a 176 heuristic search with the characters equally weighted, tree bisection and reconnection branch177 swapping, and 10 random stepwise additions. The optimal model of nucleotide substitution for 178 ML inference was evaluated by the likelihood-ratio test and selected by means of the corrected 179 Akaike Information Criterion with Jmodeltest 2.1.7 (Darriba et al., 2012). The TVM+I (for COI), 180 and the TIM1+I (for 16S-rRNA) substitution models were used as evolutionary paradigms. 181 Statistical support for the resulting phylogenies was assessed by the bootstrap method with 1,000 182 replicates (Felsenstein, 1985). BI was performed with Mr. Bayes 3.2.6 (Ronquist et al., 2012). 183 Two runs were conducted simultaneously with 4 Markov chains that went for $10^{6}$ generations, 184 sampling every 100 generations. The first 10,001 generations of each run were discarded as 185 burn-in, and the remaining 18,000 trees were used to estimate posterior probabilities. In addition, 186 the number of haplotypes in the dataset was explored with DnaSP 5.10 (Librado \& Rozas, 2009) 187 and the genetic distances estimated in MEGA 6.06 through the use of the number of differences $188(p)$ and the K2P-substitution model. Since we obtained shorter $16 S-r R N A$ sequences than 189 previously reported for $B$. peregrina from Argentina that did not include previously 190 characterized molecular diversity (Standley et al., 2011), the COI data were employed only for 191 estimating the number of haplotypes and genetic distances.

192

193

Species-distribution model

The study area comprised all of the South-American countries. The occurrence data for $B$. peregrina were retrieved from the scientific literature, and from malacological collections and international databases (Table 2). All together, 689 spatially unique records were used. When the coordinates of localities were lacking, those data were derived secondarily following Wieczorek et al. (2004). Twenty-three environmental variables were used as predictors; comprising 19 climatic, 3 hydrologic, and 1 topographical (Table 3). The variables were downloaded from WorldClim (http://www.worldclim.org) and HydroSHEDS (http://hydrosheds.cr.usgs.gov) at a spatial resolution of 30 arc seconds $\left(\sim 1 \mathrm{~km}^{2}\right)$. WorldClim and HydroSHEDS provide climatic 202 information derived from weather stations spanning 1950-2000 and hydrographic data obtained 
203 from a STRM digital-elevation model, respectively (Hijmans et al., 2005; Lehner et al., 2008).

204 These variables have been commonly employed for generating distribution models in gastropods, 205 including freshwater members, such as those belonging to the genus Biomphalaria (Scholte et 206 al., 2012; Vogler et al., 2013; Pedersen et al., 2014; Beltramino et al., 2015; Martín et al., 2016). 207 All environmental layers were trimmed to the study area. The potential-distribution model was 208 estimated by using a maximum entropy algorithm in MaxEnt 3.3.3k (Phillips et al., 2006; 209 Phillips \& Dudík, 2008). The data were randomly divided into the training data (75\% of 210 occurrences) and the model-testing data (the remaining 25\%). The output was computed as 211 logistic, which setting returns a map with an estimated probability ranging between 0 (no 212 probability of the species presence) and 1 (high probability of presence). The resulting model 213 was assessed by estimating the area under the receiver-operating-characteristic curve (ROC214 curve analyses; Fielding \& Bell, 1997). The relative contribution of variables to the development 215 of the model was evaluated by means of a jackknife test and through the response curves 216 obtained in MaxEnt following Meichtry de Zaurlín et al. (2016).

217

\section{RESULTS}

219

220

221

222

223

224

225

226

227

228

229

230

231

232

\section{Morphological examination}

Shell (Fig. 1, panel A). The empty shell is fundamentally light brown in color, with the growth lines clearly visible. The whorls, up to $5 \frac{3}{4}$ in number, increase slowly and display a rounded surface on both sides. The shells exhibit a more or less marked deflection of the outer whorl to the left. The maximum value for the larger diameter was $13.5 \mathrm{~mm}$ (mean $=9.77 \mathrm{~mm}$, $\mathrm{SD}=1.54 \mathrm{~mm}, \mathrm{n}=12)$; the maximum value for the smaller diameter was $8.98 \mathrm{~mm}($ mean $=7.53$ $\mathrm{mm}, \mathrm{SD}=1.40 \mathrm{~mm}, \mathrm{n}=11)$. The greatest height has been $4.6 \mathrm{~mm}($ mean $=3.86 \mathrm{~mm}, \mathrm{SD}=0.64$ $\mathrm{mm}, \mathrm{n}=12)$.

Radula (Fig 1, panels B to E). The central tooth is rather asymmetrical, bicuspid, with or without accessory cusps, with the base without special features. There are 106 rows of teeth; with 8 laterals and 12 marginals per half row. The first lateral tooth is tricuspid with the mesocone more developed, and with the free border rounded or in the shape of a sword point. A crest with a central depression toward the posterior part of the tooth is evident. Finally, the marginal teeth are without special features. Radular formula: [20-1-20] 106. 
Jaw. The jaw is T-shaped, with the dorsal part composed of a single crescent-shaped

234

235

236

237

238

239

240

241

242

243

244

245

246

247

248

249

250

251

252

253

254

255

256

257

258

259

260

261

262

263

piece. The features correspond to the standard description of the species and do not differ from those of other Biomphalaria species.

Genital system. The specimens showed the typology described for B. peregrina, without any special variations as ilustrated in Rumi (1991). The following distinctive characters are highlighted: in the male genital system, the vas deferens was wider distally and narrower than the the middle portion of the penis sheath; the number of the prostatic diverticula was 12 to 14 . In the female system, the apical portion of the spermathecal body was almost always covered by an anterior and long prostatic diverticulum; the vaginal pouch was well developed.

\section{Phylogenetic analysis}

The BLASTN search results, with the obtained partial COI and $16 S$-rRNA sequences from the Pinturas River as the query sequences, showed top-ranking scores and a $100 \%$ sequence identity with sequences available in the GenBank from Agua Escondida, Mendoza (Argentina) and confirmed their identity as B. peregrina. Partial DNA sequences consisted of $655 \mathrm{bp}$ for $C O I$ and $265 \mathrm{bp}$ for $16 S-r R N A$. Both markers contained no variation among the five individuals sequenced, resulting in the existence of only one haplotype per marker. After the inclusion of GenBank sequences from other locations with subsequent alignment, six unique haplotypes were identified within the COI dataset (Fig. 2). The sequence divergence among haplotypes is presented in Table 4. Different phylogenetic analyses with either the COI or $16 S$-rRNA marker did not conflict; rather, both loci gave very similar topological organizations for the NJ, MP, and BI trees with minor differences in the ML-tree organization. In all instances, two major groups were identified, referred to as the tropical and temperate clades (Figs. 2 and 3). In terms of that subdivision, the specimens from the Pinturas River were placed within the temperate group.

\section{Species-distribution model}

Fig. 4 illustrates the potential distribution area for B. peregrina. The model conformed well to expectations, with values for the area under the curve of 0.927 for the training data and 0.905 for the test data, with a standard deviation of 0.009 . The areas with higher probability of the snail's presence were found to be mainly linked to subtropical and temperate regions of South America between $15^{\circ}$ and $45^{\circ}$ south latitude, comprising central and northeastern 
264 Argentina, central Chile, eastern Paraguay, southeastern Brazil, and southern Bolivia and 265 Uruguay. In addition, regions with a moderate to high habitat suitability were predicted for Peru, 266 Ecuador, Colombia, and Venezuela. The areas of lower habitat suitability were located in French 267 Guiana, Guyana, Suriname, Venezuela, and a large area of Brazil (Fig. 4, panel B). The jackknife 268 test showed that the mean temperature of the coldest quarter (bio11), the minimum temperature 269 of coldest month (bio6) and the annual mean temperature (bio1) were the variables that most 270 greatly influenced the model development when used in isolation (Fig. 5, panel A). The flow 271 accumulation produced a reduction in training gain when removed from the model, thus 272 indicating that that variable contained information necessary for the model. The remaining 273 predictors contributed less to the modelling. Fig. 5, panel B contains the marginal-response 274 curves for the four strongest environmental predictors - i.e. the mean temperature of the coldest 275 quarter, the minimum temperature of the coldest month, the annual mean temperature, and the 276 flow accumulation.

277

278

279

280

281

282

283

284

285

286

287

288

289

290

291

292

293

294

\section{DISCUSSION}

The conchology and anatomy of the reproductive system of the specimens from the Pinturas River were consistent with the descriptions of Paraense \& Deslandes (1956) and Paraense (1966) for B. peregrina. The shells of the individuals from that river recall the original descriptions by the first authors for Australorbis inflexus (nowadays considered synonymous with B. peregrina; Paraense, 1966) from Pouso Alegre, Minas Gerais, Brazil because of the strong inflection of the aperture located toward the left side. Nevertheless, the specimens from the Pinturas River have much wider and rounder shells on both sides than those described for $A$. inflexus. The radulae of the individuals from south Patagonia have a folding and a groove between the cuspids of the central tooth that has not been described for other populations of this species. As mentioned in the Results section, the anatomy of the male genitalia of the specimens examined here exhibited a vas deferens wider distally and narrower than the middle portion of the penis sheath, which is typical of $B$. peregrina. This feature allowed distinguishing the individuals of the Pinturas River from the similar species B. orbignyi, whose widest portion of the distal segment of the vas deferens is nearly equal in width to the penis sheath (Paraense, 1975b). On the other hand, the number of prostatic diverticula in the material examined allowed distinguishing from $B$. oligoza, whose diverticula number is much smaller (tipically 1 to 6 , rarely 
295 7), and are also poorly developed. Other morphological features which confirmed the specific 296 identity of the specimens studied as B. peregrina were the apical portion of the spermathecal 297 body -almost always covered by an anterior and long prostatic diverticulum-, and the vaginal 298 pouch well developed (Paraense 1966, 1975a). When analyzing individuals collected at Agua 299 Escondida, Mendoza, Argentina, Standley et al. (2011) found a conchology and reproductive 300 organ morphology consistent with that of typical B. peregrina, as found here for the Pinturas

301

302

303

304

305 River individuals. However, those authors stated that "the internal morphology of B. peregrina has been shown to distinguish it even from closely related species, but not from $B$. orbignyi (Spatz et al., 2000)", and consequently they did not rule out B. orbignyi as an alternative for the identity of the individuals from that location. This is not the case for the individuals of the Pinturas River, given that the statment in Standley et al. (2011) is not necessarily true, as the differentiation of $B$. peregrina and B. orbignyi rest on differences in the wider portion of the distal segment of the vas deferens (Paraense, 1975b).

In addition, the morphologically identified specimens from the Pinturas River were confirmed genetically as being $B$. peregrina and a single haplotype was found among the five individuals analysed for each mitochondrial-marker loci examined. Likewise, Standley et al. (2011) reported the absence of variation in the COI marker for the population studied from Agua Escondida, Mendoza, Argentina. As mentioned above, despite having found the typical internal morphology of $B$. peregrina, those authors did not rule out $B$. orbignyi as a possible alternative, although the similar species was not included in that genetic approach. Those authors also suggested that the lack of variation in that population could be owing to a founding event in recent years since the species of Biomphalaria are hermaphroditic and capable of rapidly colonizing a new locality, even from a sole individual founder. Strikingly, a single COI haplotype seems be shared between the populations of Agua Escondida and the Pinturas River, which are geographically distant (roughly around $1200 \mathrm{~km}$ ). Two main (non-exclusive) alternatives might explain such pattern: $\mathrm{i}$ - the resolution of the COI sequence used is not resolutive enough to detect genetic variability and discriminate these samples, and ii- these populations share a close common evolutionary history. Further studies based on a greater number of specimens and molecular markers would be required to test these alternatives.

The phylogenetic trees revealed that the B. peregrina can be considered as divided into two clades, here referred to as the tropical and the temperate. For the COI marker, the first clade 
326 comprised exclusively individuals from Brazil, whereas the second included specimens from

327 southern Brazil and Argentina. For the $16 S-r R N A$, the sequences from Brazil all grouped 328 together within the tropical clade, whereas the temperate clade included only sequences from 329 Argentina and Uruguay. These clades could be linked to the biogeography and ecologic history 330 of $B$. peregrina in terms of the colonization of freshwater environments. Nonetheless, of 331 pertinence to emphasize here is that although $B$. peregrina possesses a wide distribution in South 332 America, at the present time only few DNA sequences are available in Genbank for this snail, as 333 well as for the morphologically similar species B. oligoza and B. orbignyi. Early molecular 334 studies based on the internal transcribed spacer region of the ribosomal DNA sequences (ITS) 335 demonstrated a closer relationship between B. peregrina and B. oligoza (Spatz et al., 2000; 336 Vidigal et al., 2000b), but still further research is required to fully understand the relationship 337 among the similar species (B. peregrina, B. oligoza, and B. orbignyi) and to verify whether 338 others molecular markers such as COI - currently unavailable for B. oligoza and B. orbignyi339 corroborates the classical morphological identification. Therefore, investigations focussing on 340 the phylogeography of $B$. peregrina are required to acquire a comprehensive understanding of its 341 evolutionary history, similar to those carried out for B. glabrata (Mavárez et al., 2002; DeJong et 342 al., 2003), especially since B. peregrina has been shown to occupy a basal position in the 343 phylogenetic analyses of the genus (DeJong et al., 2001; Jarne et al., 2011).

Biomphalaria peregrina, as its name might suggest -from the latin peregrinus, meaning wanderer, in reference to its wide geographical distribution (Paraense, 1975a)- is the species most widely distributed in South America within the genus. The occurrence of representative individuals from Venezuela down to one of the most southern areas of Patagonia in the Province of Santa Cruz demonstrates that the species possesses an ample range of environmental tolerance. Even so, the historical registration of $B$. peregrina and the area of its potential distribution described here nevertheless indicate that the species's greatest abundance and dispersion are within the Atlantic corridor in the south of Brazil as well as in the northeast and pampean region of Argentina. According to the results obtained here, and in agreement with the findings of Rumi (1991), the potential distribution of B. peregrina involves the most southerly areas of the Great-Del-Plata basin, then spreads to the west through the endorrheic basins of Córdoba -the ancient beds of the Paraná River- toward the Andes region, and finally, remaining 
357 specific altitude areas within the Andes, up to Venezuela, where the registers become quite 358 scarce. To the south, the distribution stretches from the pampas of the Buenos Aires province, 359 which area corresponds to the central-Argentine malacological region V (Núñez et al., 2010), to 360 the west and to the south, occupying areas on both sides of the Andes range. On the Argentine 361 side, B. peregrina inhabits the malacological regions VI in Cuyo, VII in northern Patagonia, and 362 to the south reaches the region VIII in southern Patagonia (Núñez et al., 2010). On the Chilean 363 side of the Andes, the species is dispersed from the region IX to IV.

364 Each species of Biomphalaria that is a natural or potential host for S. mansoni consists in 365 populations that exhibit varying degrees of susceptibility to different local strains of the parasite (Paraense \& Côrrea, 1973, 1978, 1985; Coelho et al., 2004; Simões et al., 2013; Marques et al., 2014). The susceptibility to $S$. mansoni has been shown to be heritable and linked to the gene pool of the IHs, each of which -according to its capability for reproduction through cross- or self-fertilization- produces progeny with differing degrees of parasitotrophic susceptibility (Newton, 1953; Richards \& Merritt, 1972; Richards, 1973, 1975; Coelho et al., 2004). As mentioned above in the Results section under the investigation of the genetic background of $B$. peregrina, the haplotypes were found to be bifurcated into two, those from tropical areas and those inhabithing the southern cone of South America, where the climate goes from subtropical to temperate in the Patagonian region to the south. These results are highly relevant since Paraense \& Côrrea (1973) demonstrated experimentally that populations of B. peregrina from Lapa of Paraná (in Brazil), and Chillogallo (in Ecuador) are markedly susceptible to infection with the BH (Belo-Horizonte) and SJ (San-Jose) strains of S. mansoni, though these B. peregrina strains have not yet been found to be infected in the wild. Although the susceptibility to different strains of $S$. mansoni of populations of $B$. peregrina that inhabit subtropical or temperate areas have still not been evaluated, other Biomphalaria species such as B. tenagophila and $B$. straminea in the northeast of Argentina have indeed been found to serve experimentally as IHs of several strains of S. mansoni (Borda \& Rea, 1997; Simões et al., 2013). In this context, new studies on the susceptibility and genetic variation of diverse variants and morphotypes of $B$. peregrina are needed involving populations that contain the haplotypes identified here as subtropical and temperate. For example, those individuals characterized within the snails at the Pinturas River, for their part, presented morphologic similarities to a morphotype of $B$. peregrina registered in Minas Gerais, Brazil; but that Brazilian variant, in contrast, was demonstrated 
388

389

390

391

392

393

394

395

396

397

398

399

400

401

402

403

404

405

406

407

408

409

410

411

412

413

414

415

416

417

experimentally to be not susceptible to parasitism by $S$. mansoni (Paraense \& Deslandes, 1956). Thus, determinations of this nature are fundamental for delineating the potential area of occupation of $B$. peregrina and obtaining a more realistic approximation of the corresponding potential zone of occupation of populations susceptible to parasitism, which information could be associated with the possible appearance of foci of infection and a southward dispersion of the endemium. In addition, regions with a moderate to high habitat suitability for B. peregrina were predicted within the Andes (Peru, Ecuador, Colombia, and Venezuela), which indicates a preference for relatively cold climatic ranges in that area and could have also implications on the possible risks of schistosomiasis in some specific altitudinal regions in the Andes.

Finally, as mentioned above, further research is still needed for a better understanding of the evolutionary history, ecology, parasitic susceptibility, and genetic variarion among the potential IHs of $S$. mansoni in South America, such as B. peregrina; which species is comparatively underrepresented in current research on planorbid snails despite its wide distribution in South America, as indicated by the evidence of the record of the new population described here in southern Patagonia.

\section{ACKNOWLEDGEMENTS}

The authors would like to thank Dr. Monika Hamann (Centro de Ecología Aplicada del Litoral, CONICET) and three anonymous reviewers for providing valuable comments on an early version of the manuscript, and Patricia Sarmiento (Museo de La Plata) who obtained the scanning photographs. Finally, the authors are grateful to Dr. Donald F. Haggerty, a retired academic career investigator and native English speaker, for translating the manuscript from the original Spanish and editing the final version.

\section{REFERENCES}

Altschul SF, Gish W, Miller W, Myers EW, Lipman DJ. 1990. Basic local alignment search tool. Journal of Molecular Biology 215:403-410.

Barbosa FS, Coelho MV, Carneiro E. 1956. Cross-breeding of Australorbis glabratus and Biomphalaria boissyi. Transactions Royal Society of Tropical Medicine \& Hygiene 50:296297. DOI 10.1016/0035-9203(56)90038-4 
418 Barbosa FS, Hubendick B, Malek E, Wright G. 1961. The generic names Australorbis,

419

420

421

422

423

424

425

426

427

428

429

430

431

432

433

434

435

436

437

438

439

440

441

442

443

444

445

446

447 Biomphalaria, Platytaphius, Taphius and Tropicorbis. Annals and Magazine of Natural History 4:371-375. DOI 10.1080/00222936108651121

Beltramino AA, Vogler RE, Gutiérrez Gregoric DE, Rumi A. 2015. Impact of climate change on the distribution of a giant land snail from South America: predicting future trends for setting conservation priorities on native malacofauna. Climatic Change 131:621-633. DOI 10.1007/s10584-015-1405-3

Bertoni AW. 1925. Sobre moluscos del Paraguay. Revista de la Sociedad Científica del Paraguay 2:71-73.

Biese WA. 1951. Revisión de los moluscos terrestres y de agua dulce provistos de concha de Chile. Parte 4: Planorbidae. Boletín Museo de Historia Natural, Chile 25:115-137.

Bonetto AA, Rumi A, Tassara MP. 1990. Notas sobre el conocimiento limnológico de los gasterópodos paranenses y sus relaciones tróficas. II. Planorbidae, con espectos distribucionales y sanitarios. Ecosur 16:69-84.

Borda CE, Rea MJF. 1997. Susceptibilidad de Biomphalaria tenagophila de las cuencas de los ríos Paraná y Uruguay a Schistosoma mansoni. Revista Panamericana de la Salud Pública 1:167-173. DOI 10.1590/S1020-49891997000300001

Caldeira RL, Vidigal THDA, Paulinelli ST, Simpson AJG, Carvalho OS. 1998. Molecular identification of similar species of the genus Biomphalaria (Mollusca: Planorbidae) determined by a PCR-RFLP. Memórias do Instituto Oswaldo Cruz 93:219-225. DOI 10.1590/S0074-02761998000700039

Castellanos ZA, Miquel SE. 1991. Distribución de los Pulmonados Basommatophora. Fauna de la República Argentina. Programa de Fauna de Agua Dulce, Museo de La Plata - CONICET 15(8):1-9.

Ciocco NF, Scheibler EE. 2008. Malacofauna of the littoral benthos of a saline lake in southern Mendoza, Argentina. Fundamental and Applied Limnology 172:87-98. DOI 10.1127/18639135/2008/0172-0087

Coelho PMZ, Carvalho OS, Andrade ZA, Martins-Sousa RL, Rosa FM, Barbosa L, Pereira CAJ, Caldeira RL, Jannotti-Passos LK, Godard ALB, Moreira LA, Oliveira GC, Franco GR, Teles HMS, Negrão-Corrêa D. 2004. Biomphalaria tenagophila/Schistosoma mansoni 
448

449

450

451

452

453

454

455

456

457

458

459

460

461

462

463

464

465

466

467

468

469

470

471

472

473

474

475

476

477

interaction: premises for a new approach to biological control of schistosomiasis. Memorias do Instituto Oswaldo Cruz 99:109-111. DOI 10.1590/S0074-02762004000900020

Collado GA, Méndez MA. 2012. Phylogenetic relationships and taxonomy of Altiplano populations of Biomphalaria (Gastropoda: Planorbidae): inference from a multilocus approach. Zoological Journal of the Linnean Society 165:795-808. DOI 10.1111/j.10963642.2012.00829.x

Collado GA, Vila I, Méndez MA. 2011. Monophyly, candidate species and vicariance in Biomphalaria snails (Mollusca: Planorbidae) from the Southern Andean Altiplano. Zoologica Scripta 40:613-622. DOI 10.1111/j.1463-6409.2011.00491.x

Cousin A. 1887. Faune malacologique de la Republique de l'Équateur. Bulletin Societe Zoologique France 12:187-287.

Darriba D, Taboada GL, Doallo R, Posada D. 2012. jModelTest 2: more models, new heuristics and parallel computing. Nature Methods 9:772. DOI 10.1038/nmeth.2109

DeJong RJ, Morgan JAT, Paraense L, Pointier J-P, Amarista M, Ayeh-Kumi PFK, Babiker A, Barbosa CS, Brémond P, Canese AP, de Souza CP, Dominguez C, File S, Gutierrez A, Incani RN, Kawano T, Kazibwe F, Kpikpi J, Lwambo NJS, Mimpfoundi R, Njiokou F, Poda JN, Sene M, Velásquez LE, Yong M, Adema CM, Hofkin BV, Mkoji GM, Loker ES. 2001. Evolutionary relationships and biogeography of Biomphalaria (Gastropoda: Planorbidae) with implications regarding its role as host of the human bloodfluke Schistosoma mansoni. Molecular Biology and Evolution 18:2225-2239.

DeJong RJ, Morgan JAT, Wilson WD, Al-Jaser MH, Appleton CC, Coulibaly G, D'Andrea PS, Doenhoff MJ, Haas W, Idris MA, Magalhães LA, Moné H, Mouahid G, Mubila L, Pointier JP, Webster JP, Zanotti-Magalhães EM, Paraense WL, Mkoji GM, Loker ES. 2003. Phylogeography of Biomphalaria glabrata and B. pfeifferi, important intermediate hosts of Schistosoma mansoni in the New and Old World tropics. Molecular Ecology 12:30413056. DOI 10.1046/j.1365-294X.2003.01977.x

d'Orbigny A. 1835. Synopsis terrestrium, et fluviatilium molluscorum, in suo per Americam meridionalem intinere, ab A. d'Orbigny, collectorum. Magasin de Zoologie 5(61/62):1-44.

Dunker G. 1848. Diagnoses specierum novarum generis Planorbis collectionis Cumingianæ. Proceedings of the Zoological Society of London 16:40-43. 
478

479

480

481

482

483

484

485

486

487

488

489

490

491

492

493

494

495

496

497

498

499

500

501

502

503

504

505

506

507

508

Estrada VE, Velásquez LE, Caldeira RL, Bejarano EE, Rojas W, Carvalho OS. 2006. Phylogenetics of South American Biomphalaria and description of a new species (Gastropoda: Planorbidae). Journal of Molluscan Studies 72:221-228. DOI 10.1093/mollus/ey1003

Felsenstein J. 1985. Confidence limits on phylogenies: an approach using the bootstrap. Evolution 39:783-791. DOI 10.2307/2408678

Fielding AH, Bell JF. 1997. A review of methods for the assessment of prediction errors in conservation presence/absence models. Environmental Conservation 24:38-49.

Flores V, Brugni N. 2005. Notocotylus biomphalariae n. sp. (Digenea: Notocotylidae) from Biomphalaria peregrina (Gastropoda: Pulmonata) in Patagonia, Argentina. Systematic Parasitology 61:207-214. DOI 10.1007/s11230-005-3166-2

Folmer O, Black M, Hoeh W, Lutz R, Vrijenhoek R. 1994. DNA primers for amplification of mitochondrial cytochrome c oxidase subunit I from diverse metazoan invertebrates. Molecular Marine Biology and Biotechnology 3:294-299.

Hall TA. 1999. BioEdit: a user-friendly biological sequence alignment editor and analysis program for Windows 95/98/NT. Nucleic Acids Symposium Series 41:95-98.

Hijmans RJ, Cameron SE, Parra JL, Jones PG, Jarvis A. 2005. Very high resolution interpolated climate surfaces for global land areas. International Journal of Climatology 25:1965-1978. DOI 10.1002/joc.1276

Holznagel W. 1998. A nondestructive method for cleaning gastropod radulae from frozen, alcohol-fixed, or dried material. American Malacological Bulletin 14:181-183.

Jarne P, Pointier JP, David P. 2011. Biosystematics of Biomphalaria spp. with an emphasis on Biomphalaria glabrata. In: Toledo R, Fried B, eds. Biomphalaria snails and larval trematodes. New York: Springer.

Jørgensen A, Kristensen TK, Stothard JR. 2007. Phylogeny and biogeography of African Biomphalaria (Gastropoda: Planorbidae), with emphasis on endemic species of the great East African lakes. Zoological Journal of the Linnean Society 151:337-349. DOI 10.1111/j.10963642.2007.00330.x

Kloos H, Correa-Oliveira R, Ferreira Quites H, Souza MC, Gazzinelli A. 2008. Socioeconomic studies of schistosomiasis in Brazil: a review. Acta Tropica 108:194-201. DOI 10.1016/j.actatropica.2008.07.002 
509 Larkin MA, Blackshields G, Brown NP, Chenna R, McGettigan PA, McWilliam H, 510 Valentin F, Wallace IM, Wilm A, Lopez R, Thompson JD, Gibson TJ, Higgins DG. 2007.

511 Clustal $\mathrm{W}$ and Clustal $\mathrm{X}$ version 2.0. Bioinformatics 23:2947-2948. DOI $512 \quad 10.1093 /$ bioinformatics/btm404

513 Lehner B, Verdin K, Jarvis A. 2008. New global hydrography derived from spaceborne 514 elevation data. EOS. Transactions American Geophysical Union 89:93-94. DOI $515 \quad 10.1029 / 2008 E O 100001$

516 Librado P, Rozas J. 2009. DnaSP v5: a software for comprehensive analysis of DNA 517 polymorphism data. Bioinformatics 25:1451-1452. DOI 10.1093/bioinformatics/btp187

518 Marques DPA, Rosa FM, Maciel E, Negrão-Corrêa D, Teles HMS, Caldeira RL, Jannotti519 Passos LK, Coelho PMZ. 2014. Reduced susceptibility of a Biomphalaria tenagophila 520 population to Schistosoma mansoni after introducing the resistant Taim/RS strain of $B$. 521 tenagophila into Herivelton Martins Stream. PLoS ONE 9(6):e99573. DOI 522 10.1371/journal.pone.0099573

Martín PR, Ovando XMC, Seuffert ME. 2016. First record of the freshwater snail Pseudosuccinea columella (Gastropoda: Lymnaeidae) in southern Pampas (Argentina) and assessment of future spread. Molluscan Research 36:213-221. DOI 10.1080/13235818.2015.1128602

Mavárez J, Steiner C, Pointier JP, Jarne P. 2002. Evolutionary history and phylogeography of 528

Meichtry de Zaburlín N, Vogler RE, Molina MJ, Llano VM. 2016. Potential distribution of

Moreno González F. 1981. Hallazgo de portadores de Schistosoma mansoni (Sanbon, 1907) en el Paraguay. Revista Paraguaya de Microbiología 16:15-17.

Newton WL. 1953. The inheritance of susceptibility to infection with Schistosoma mansoni in 537 Australorbis glabratus. Experimental Parasitology 2:242-257. DOI 10.1016/00144894(53)90036-8 
538 Noya O, Katz N, Pointier JP, Theron A, de Noya BA. 2015. Schistosomiasis in America. In:

539 Franco-Paredes C, Santos-Preciado JI, eds. Neglected Tropical Diseases - Latin America and 540 the Caribbean. Vienna: Springer.

541 Núñez V, Gutiérrez Gregoric DE, Rumi A. 2010. Freshwater Gastropod Provinces from 542 Argentina. Malacologia 53:47-60. DOI 10.4002/040.053.0103

543 Pan American Health Organization. 2010. Control and elimination of five neglected diseases 544 in Latin America and the Caribbean, 2010-2015: analysis of progress, priorities and lines of 545 action for Limphatic filariasis, Schistosomiasis, Onchocercariasis, Trachoma and Soil546 transmitted helminthiases. Washington, D.C.: PAHO.

547 Paraense WL. 1958. The genera Australorbis, Tropicorbis, Biomphalaria, Platytaphius and 548 Taphius (Pulmonata, Planorbidae). Revista Brasileira Biologia 18:65-80.

549 Paraense WL. 1966. The synonymy and distribution of Biomphalaria peregrina in the 550 Neotropical region. Revista Brasileira de Biologia 26:269-296.

551 Paraense WL 1974. Biomphalaria oligoza n.n. for Tropicorbis philippianus (Dunker) sensu 552 Lucena. Revista Brasileira de Biologia 34:379-386.

553 Paraense WL. 1975a. Estado actual da sistemática dos Planorbídeos Brasileiros (Moll. 554 Gastropoda). Arquivos do Museu Nacional Rio de Janeiro 55:105-128.

555 Paraense WL. 1975b. Biomphalaria orbignyi sp. n. from Argentina (Gastropoda: 556 Basommatophora: Planorbidae). Revista Brasileira de Biologia 35:211-222.

557 Paraense WL. 1988. Biomphalaria kuhniana (Clessin, 1883), planorbid mollusc from South 558 America. Memórias do Instituto Oswaldo Cruz 83:1-12. DOI 10.1590/S007455902761988000100001

560 Paraense WL. 2003. A bird's eye survey of Central American planorbid molluscs. Memorias do 561 Instituto Oswaldo Cruz 98:51-67. DOI 10.1590/S0074-02762003000100008

Paraense WL. 2004. Planorbidae, Lymnaeidae and Physidae of Ecuador (Mollusca; Basommatophora). Memorias do Instituto Oswaldo Cruz 99:357-362. DOI 10.1590/S007402762004000400003

Paraense WL. 2008. Histórico do gênero Biomphalaria, morfologia e sistemática morfológica. 566 567 In: Carvalho OS, Coelho PMZ, Lenzi HL, eds. Schistosoma mansoni \& esquistossomose: uma visão multidisciplinar. Rio de Janeiro: Editora Fiocruz. DOI 10.7476/9788575413708 
568 Paraense WL, Côrrea LR. 1973. Suceptibility of Biomphalaria peregrina from Brazil and

569

570

571

572

573

574

575

576

577

578

579

580

581

582

583

584

585

586

587

588

589

590

591

592

593

594

595

596

597

Ecuador to two strains of Schistosoma mansoni. Revista do Instituto de Medicina Tropical de São Paulo 15:127-130.

Paraense WL, Côrrea LR. 1978. Differential susceptibility of Biomphalaria tenagophila populations to infection with a strain of Schistosoma mansoni. Journal of Parasitology 64:822-826. DOI 10.2307/3279509

Paraense WL, Côrrea LR. 1985. Further experiments on susceptibility of Biomphalaria amazonica to Schistosoma mansoni. Memorias do Instituto Oswaldo Cruz 80:259-262. DOI 10.1590/S0074-02761985000300001

Paraense WL, Deslandes N. 1956. Australorbis inflexus sp. $\mathrm{n}$. from Brazil. Revista Brasileira de Biologia 16:149-158.

Paravicini G. 1894. Viaggio del Dottor Alfredo Borelli nella Repubblica Argentina en el Paraguay, IV. Bollettino dei Musei di Zoologia e Anatomia Comparata della R. Universita di Torino 9:1-10.

Pedersen UB, Stendel M, Midzi N, Mduluza T, Soko W, Stensgaard AS, Vennervald BJ, Mukaratirwa S, Kristensen TK. 2014. Modelling climate change impact on the spatial distribution of fresh water snails hosting trematodes in Zimbabwe. Parasites \& Vectors 7:536. DOI 10.1186/s13071-014-0536-0

Pepe MS, Caldeira RL, Carvalho OS, Muller G, Jannotti-Passos LK, Rodrigues AP, Amaral HL, Berne MEA. 2009. Biomphalaria molluscs (Gastropoda: Planorbidae) in Rio Grande do Sul, Brazil. Memórias do Instituto Oswaldo Cruz 104:783-786. DOI 10.1590/S0074-02762009000500020

Phillips SJ, Dudík M. 2008. Modeling of species distributions with Maxent: new extensions and a comprehensive evaluation. Ecography 31:161-175. DOI 10.1111/j.2007.0906-7590.05203.x

Phillips SJ, Anderson RP, Schapire RE. 2006. Maximum entropy modeling of species geographic distributions. Ecological Modelling 190:231-259. DOI 10.1016/j.ecolmodel.2005.03.026

Prando HF, Bacha RE. 1995. Ocorrência e controle de moluscos gastrópodes em arroz irrigado no sistema pré-germinado, em Santa Catarina. In: Anais XXI Reunião da Cultura do Arroz Irrigado. Porto Alegre, IRGA, 229-231. 
598 Quintana MG. 1982. Catálogo preliminar de la malacofauna del Paraguay. Revista del Museo 599 Argentino de Ciencias Naturales Bernardino Rivadavia 11:61-158.

600 Ramírez J, Ramírez R. 2010. Analysis of the secondary structure of mitochondrial LSU rRNA 601 of Peruvian land snails (Orthalicidae: Gastropoda). Revista Peruana de Biología 17:53-57.

602 Richards CS. 1973. Susceptibility of adult Biomphalaria glabrata to Schistosoma mansoni 603 infection. American Journal of Tropical Medicine and Hygiene 22:748-756.

604 Richards CS. 1975. Genetic factors in susceptibility of Biomphalaria glabrata for different 605 strains of Schistosoma mansoni. Parasitology 70:231-241. DOI 606 $10.1017 / \mathrm{S} 0031182000049696$

Richards CS, Merritt, JW Jr. 1972. Genetic factors in the susceptibility of juvenile Biomphalaria glabrata to Schistosoma mansoni infection. American Journal of Tropical Medicine and Hygiene 21:425-434.

Ronquist F, Teslenko M, van der Mark P, Ayres DL, Darling A, Höhna S, Larget B, Liu L, Suchard MA, Huelsenbeck JP. 2012. MrBayes 3.2: efficient bayesian phylogenetic inference and model choice across a large model space. Systematic Biology 61:539-542. DOI $10.1093 /$ sysbio/sys029

Rumi A. 1991. La familia Planorbidae Rafinesque, 1815 en la República Argentina. Fauna de agua dulce de la República Argentina, Programa de Fauna de Agua Dulce, Museo de La Plata-CONICET 15(9):3-51.

Rumi A, Vogler RE. 2014. Neglected diseases: contribution from continental malacology. In: de Toledo Piza AR, de Freitas Tallarico L, Orlandi Introíni G, Barbosa dos Santos S, eds. Medical and Applied Malacology Crossing Boundaries: Integrative Approaches to Malacology. Newcastle upon Tyne: Cambridge Scholars Publishing. 20-29.

Rumi A, Martín SM, Tassara MP, Darrigran GA. 1996. Moluscos de agua dulce de la Reserva Natural e Histórica Isla Martín García, Río de la Plata, Argentina. Comunicaciones de la Sociedad Malacológica del Uruguay 8:7-12.

Rumi A, Tassara MP, Bonetto AA. 1997. Distribución de las species de Planorbidae en la Argentina y su relación con el riesgo de esquistosomiasis. Ecosur 17:1-19.

Rumi A, Gutiérrez Gregoric DE, Núñez V, César II, Roche MA, Tassara MP, Martín SM, López Armengol MF. 2006. Freshwater Gastropoda from Argentina: species richness, 
628

629

630

631

632

633

634

635

636

637

638

639

640

641

642

643

644

645

646

647

648

649

650

651

652

653

654

655

656

657

distribution patterns, and an evaluation of endangered species. Malacologia 49:189-208. DOI $10.4002 / 1543-8120-49.1 .189$

Rumi A, Gutiérrez Gregoric DE, Núñez V, Darrigran GA. 2008. Malacología Latinoamericana. Moluscos de agua dulce de Argentina. Revista de Biología Tropical 56:77111.

Russell RH. 1972. Final TDY Report: 15 March-30 June, 1972 USAID Contract to Paraguay. New México State Universíty: 1-9.

Scarabino F. 2004. Lista sistemática de los gastropoda dulciacuícolas vivientes de Uruguay. Comunicaciones de la Sociedad Malacológica del Uruguay 8:347-356.

Schade FH. 1965. Lista de los moluscos del Guayrá (Víllarrica, Paraguay) conocidos hasta el presente. Comunicaciones de la Sociedad Malacológica del Uruguay 1:208-223.

Scholte RGC, Carvalho OS, Malone JB, Utzinger J, Vounatsou P. 2012. Spatial distribution of Biomphalaria spp., the intermediate host snails of Schistosoma mansoni, in Brazil. Geospatial Health 6:S95-S101. DOI 10.4081/gh.2012.127

Simões LF, Camargo EAF, Bastos LD, Neves MF, Carvalho JF, Magalhães LA, ZanottiMagalhães EM. 2013. Susceptibility of Argentinean Biomphalaria tenagophila and Biomphalaria straminea to infection by Schistosoma mansoni and the possibility of geographic expansion of mansoni schistosomiasis. Revista da Sociedade Brasileira de Medicina Tropical 46:611-616. DOI 10.1590/0037-8682-0131-2013

Spatz L, Vidigal THDA, Silva MCA, González Cappa SM, Carvalho OS. 2000. Characterization of Biomphalaria orbignyi, B. peregrina and B. oligoza by polymerase chain reaction and restriction enzyme digestion of the internal transcribed spacer region of the RNA ribosomal gene. Memórias do Instituto Oswaldo Cruz 95:807-814. DOI 10.1590/S007402762000000600010

Standley CJ, Pointier JP, Issia L, Wisnivesky-Colli C, Stothard JR. 2011. Identification and characterization of Biomphalaria peregrina (Orbignyi, 1835) from Agua Escondida in northern Patagonia, Argentina. Journal of Natural History 45:347-356. DOI $10.1080 / 00222933.2010 .531153$

Swofford DL. 2002. PAUP* Phylogenetic Analysis Using Parsimony (*and Other Methods). Version 4. Sunderland: Sinauer Associates. 
658 Tamura K, Stecher G, Peterson D, Filipski A, Kumar S. 2013. MEGA6: Molecular

659

660

661

662

663

664

665

666

667

668

669

670

671

672

673

674

675

676

677

678

679

680

681

682

683

684

685

686

687 evolutionary genetics analysis version 6.0. Molecular Biology and Evolution 30:2725-2729. DOI 10.1093/molbev/mst197

Teles HMS, Pereira PAC, Richinitti LMZ. 1991. Distribução de Biomphalaria (Gastropoda, Planorbidae) nos Estados do Rio Grande do Sul e Santa Catarina, Brasil. Revista de Saúde Pública, São Paulo 25:350-352. DOI 10.1590/S0034-89101991000500004

Vidigal THDA, Spatz L, Nunes DN, Simpson AJG, Carvalho OS, Dias Neto E. 1998. Biomphalaria spp: identification of the intermediate snail hosts of Schistosoma mansoni by polymerase chain reaction amplification and restriction enzyme digestion of the ribosomal RNA gene intergenic spacer. Experimental Parasitology 89:180-187. DOI 10.1006/expr.1998.4286

Vidigal THDA, Caldeira RL, Simpson AJG, Carvalho OS. 2000a. Further studies on the molecular systematics of Biomphalaria snails from Brazil. Memórias do Instituto Oswaldo Cruz 95:57-66. DOI 10.1590/S0074-02762000000100009

Vidigal THDA, Kissinger JC, Caldeira RL, Pires ECR, Monteiro E, Simpson AJG, Carvalho OS. 2000b. Phylogenetic relationships among Brazilian Biomphalaria species (Mollusca: Planorbidae) based upon analysis of ribosomal ITS2 sequences. Parasitology 121:611-620. DOI 10.1017/S0031182000006831

Vidigal THDA, Spatz L, Kissinger JC, Redondo RAF, Pires ECR, Simpson AJG, Carvalho OS. 2004. Analysis of the first and second internal transcribed spacer sequences of the ribosomal DNA in Biomphalaria tenagophila complex (Mollusca: Planorbidae). Memorias do Instituto Oswaldo Cruz 99:153-158. DOI 10.1590/S0074-02762004000200007

Vogler RE, Beltramino AA, Sede MM, Gutiérrez Gregoric DE, Núñez V, Rumi A. 2013. The giant African snail, Achatina fulica (Gastropoda: Achatinidae): using bioclimatic models to identify South American areas susceptible to invasion. American Malacological Bulletin 31:39-50. DOI 10.4003/006.031.0115

Vogler RE, Beltramino AA, Peso JG, Rumi A. 2014. Threatened gastropods under the evolutionary genetic species concept: redescription and new species of the genus Aylacostoma (Gastropoda: Thiaridae) from High Paraná River (Argentina-Paraguay). Zoological Journal of the Linnean Society 172:501-520. DOI 10.1111/zoj.12179 
688 Vogler RE, Beltramino AA, Strong EE, Rumi A, Peso JG. 2016. Insights into the 689 evolutionary history of an extinct South American freshwater snail based on historical DNA. $690 \quad$ PLoS ONE 11(12):e0169191. DOI 10.1371/journal.pone.0169191

691 Wieczorek J, Guo Q, Hijmans RJ. 2004. The point-radius method for georeferencing locality 692 descriptions and calculating associated uncertainty. International Journal of Geographical 693 Information Science 18:745-767. DOI 10.1080/13658810412331280211

694 World Health Organization. 2015. Investing to overcome the global impact of neglected 695 tropical diseases. Third WHO Report on Neglected Tropical Diseases. Geneva: World Health 696 Organization. 


\section{Figure 1}

External shell morphology and radula of Biomphalaria peregrina from the Pinturas River, Argentina.

Panel A: Right, left, and ventral views. Panels B-D: Detail of the rachidian or central (CT) and lateral teeth (LT); ec, ectocone; en, endocone; me, mesocone. Panel E: Detail of marginal teeth.

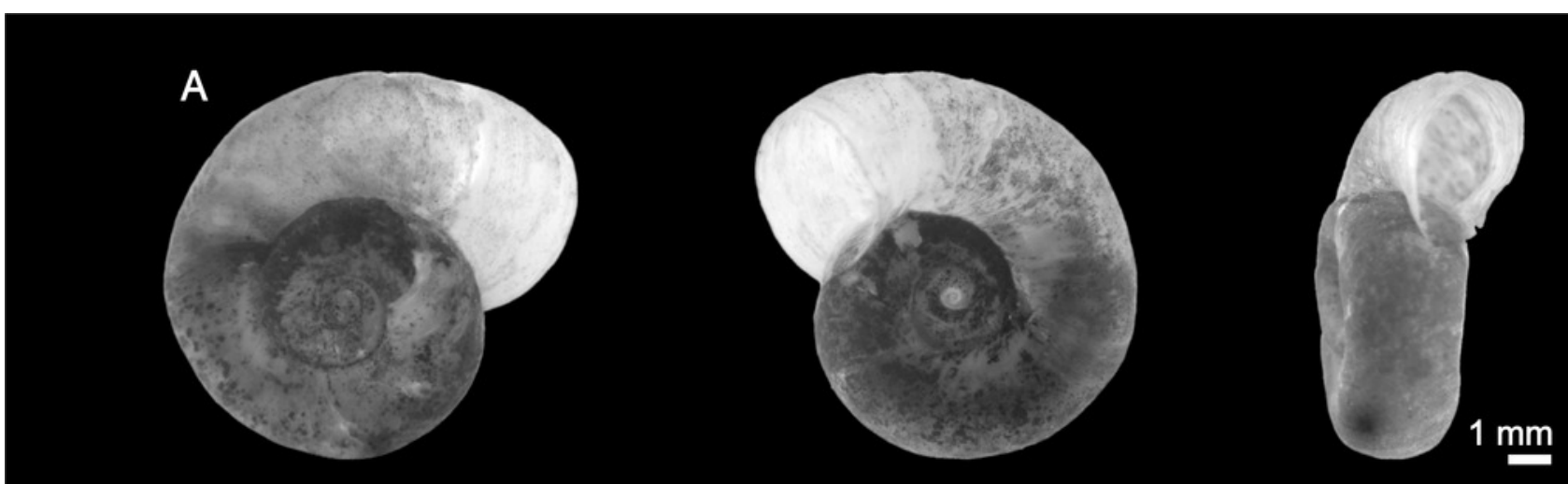

B

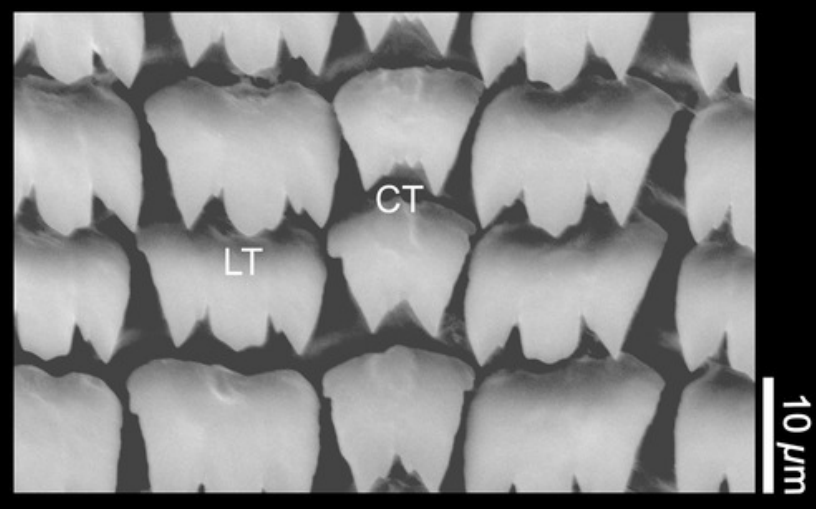

C

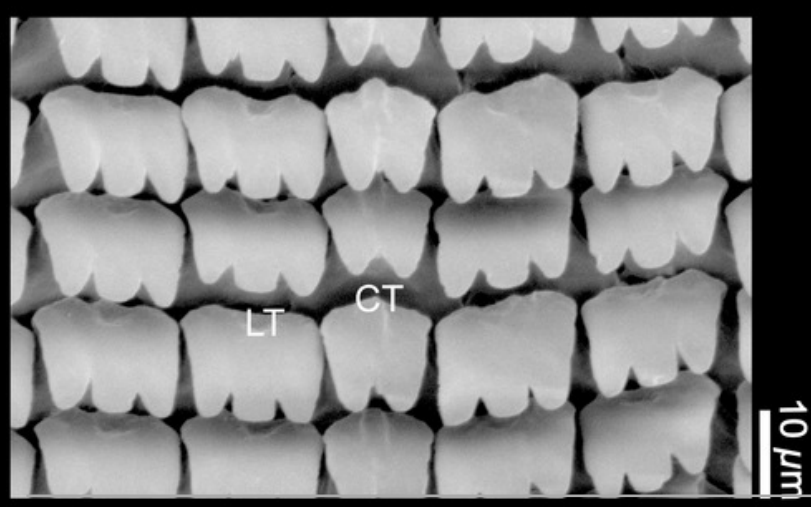

D

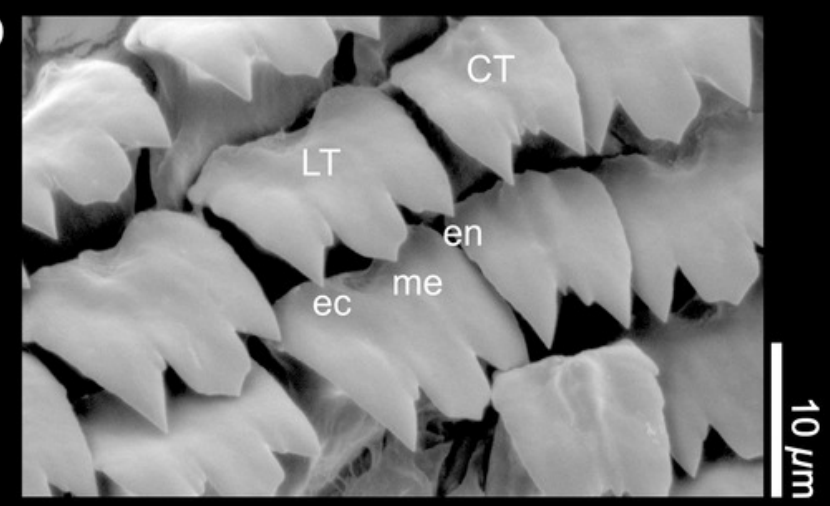

$\mathrm{E}$

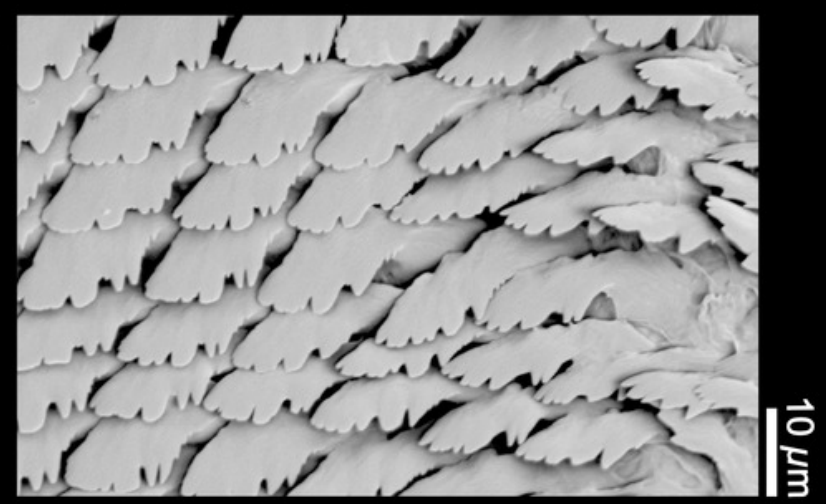




\section{Figure 2}

Bayesian tree of Biomphalaria peregrina based on the partial COI gene.

The bootstrap values for the NJ, MP, ML trees and posterior-probability values for $\mathrm{BI}$ are shown above and below the branches. The numbers within parentheses are GenBankaccession numbers. The geographical distribution of the localities sampled and the haplotypes $(\mathrm{H})$ is shown. The literature references to the sequences are given in Table 1.

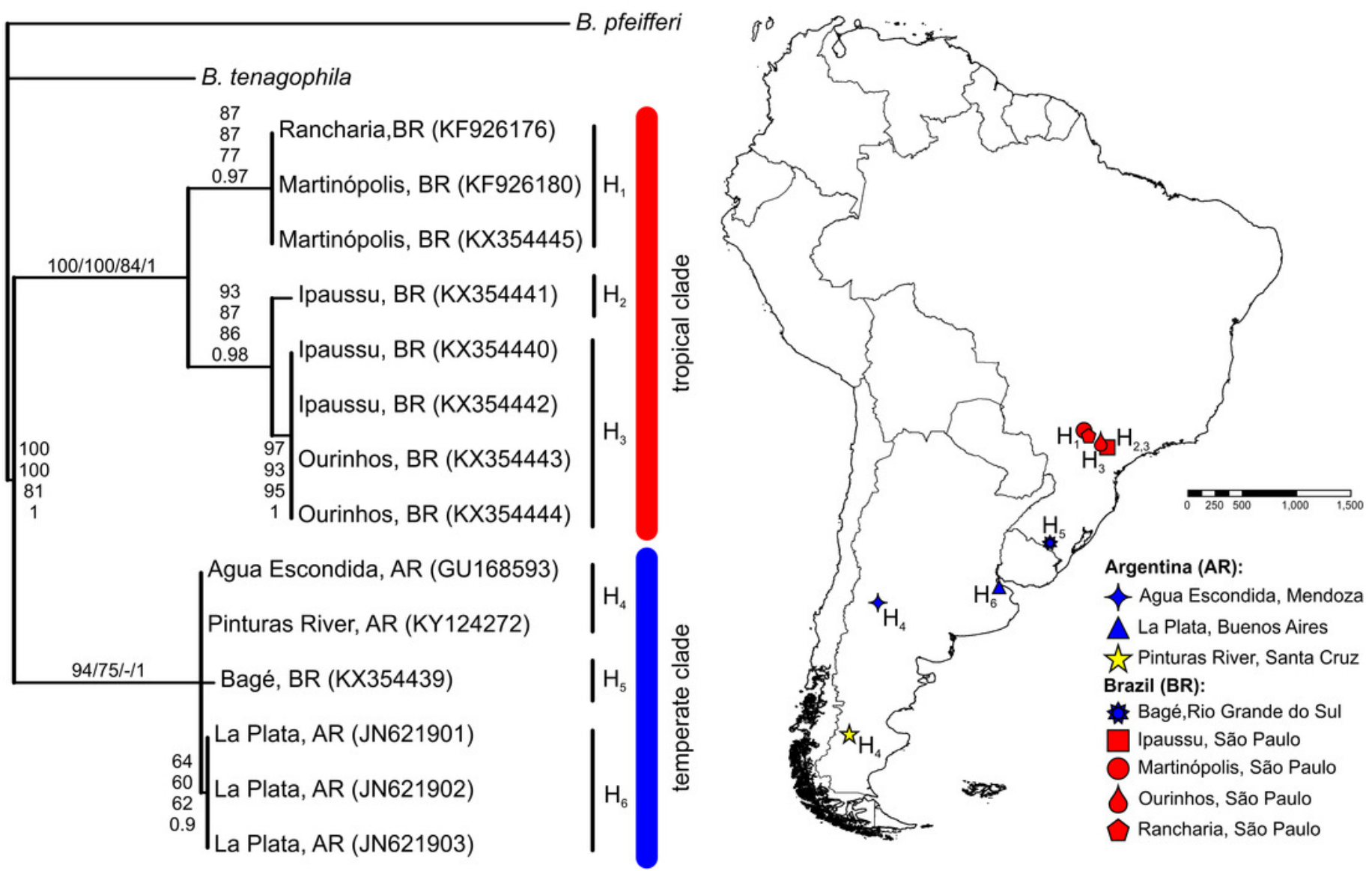


Figure 3

Bayesian tree of Biomphalaria peregrina based on the partial 16S-rRNA gene.

The bootstrap values for the NJ, MP, ML trees and posterior-probability values for $\mathrm{BI}$ are shown above and below the branches. The numbers within parentheses are GenBankaccession numbers. The geographical distribution of the localities sampled is shown. The literature references to the sequences are given in Table 1.

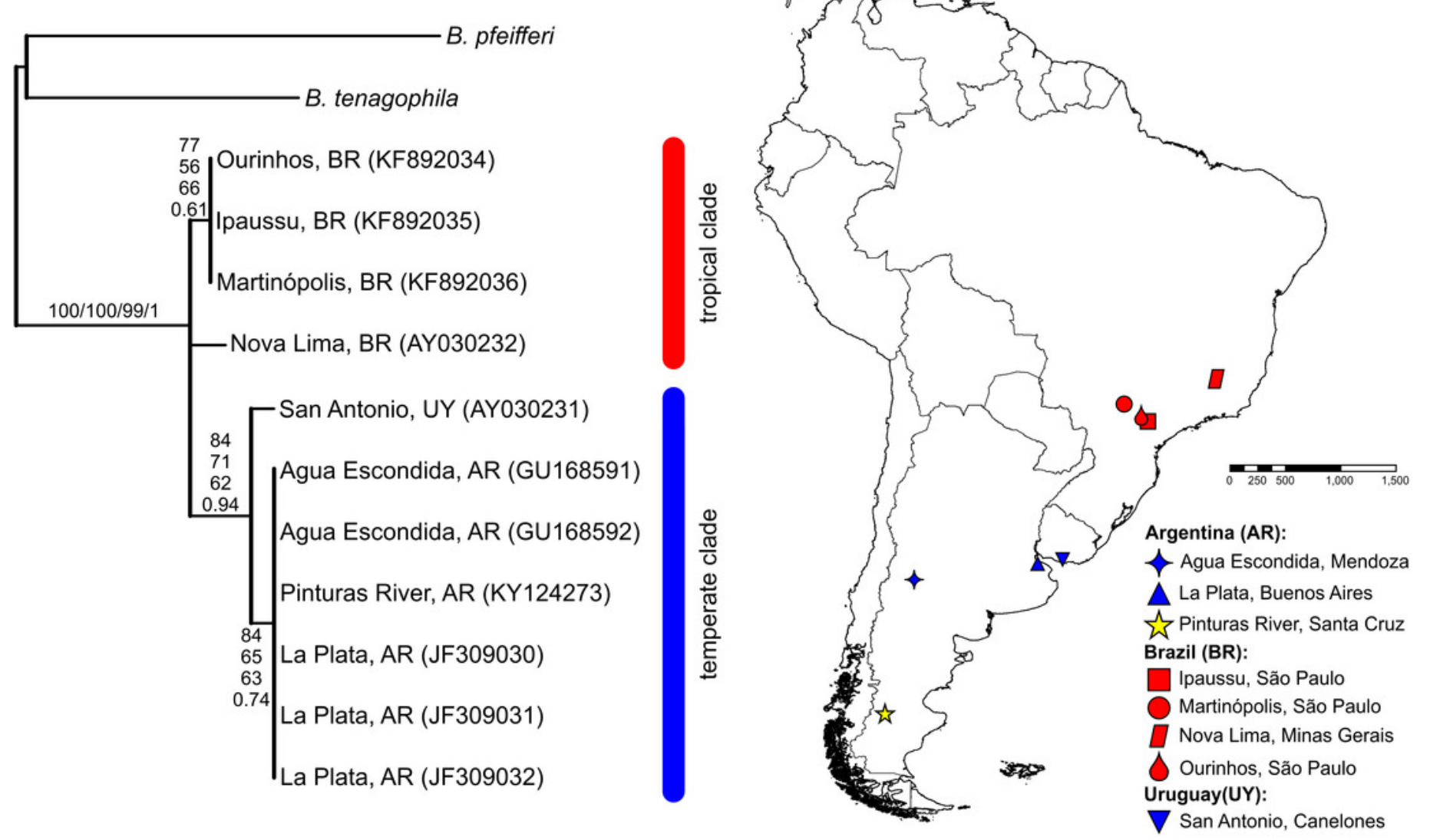




\section{Figure 4}

Distribution of Biomphalaria peregrina in South America.

Panel A: Records of the snail's presence used in the modelling approach, with the southernmost record being from the Pinturas River, Argentina, as indicated by a yellow star. Panel B: Potential distribution in logistic format. The color code for location suitability and thus probability of the snail's presence: red, very high; yellow, high; azure, moderate; blue, low.

A

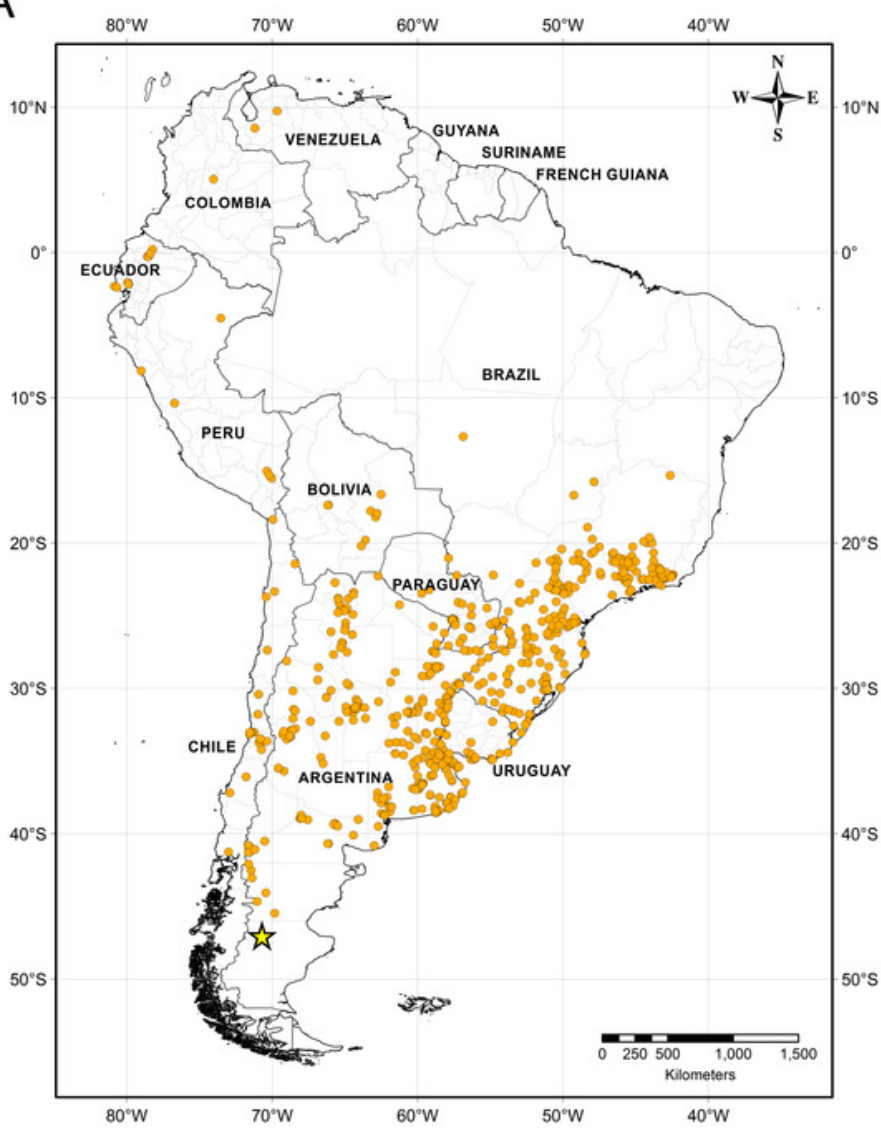

B

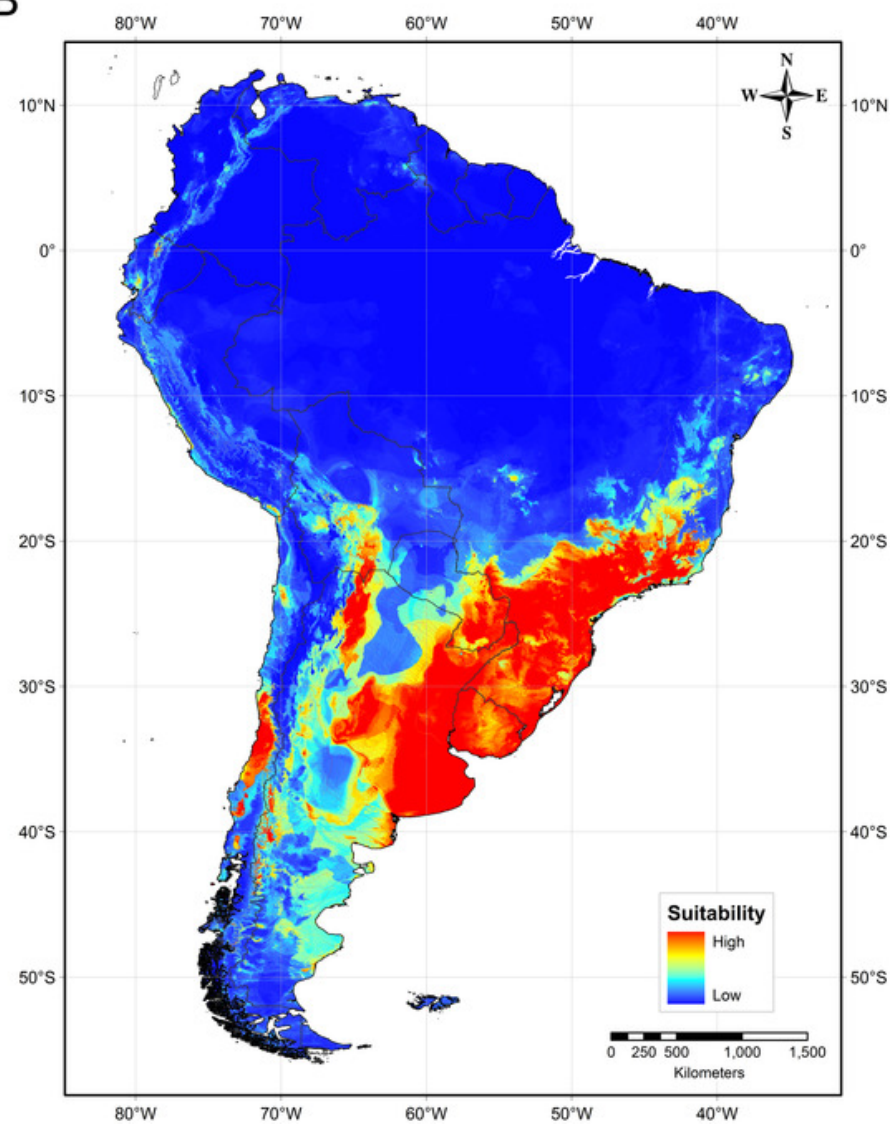




\section{Figure 5}

Relative influence of the environmental variables for the potential distribution of Biomphalaria peregrina in South America.

Panel A: Jackknife test determining the contribution of each environmental variable to the development of the model. In the figure, the regularized training gain is plotted on the abscissa for each of the variables indicated on the ordinate. Color code: gray, without a variable; blue, with only a single variable; red, with all variables. Panel B: Marginal-response curves for the four strongest environmental predictors. In each of the figures, the logistic output, a measure of the probability of presence, is plotted on the ordinate for-from the upper to the lower figure - the mean temperature of the coldest quarter (bio11), the minimum temperature of the coldest month (bio6), the annual mean temperature (bio1), and the flow accumulation (acc). 

A
A
$\frac{10}{0}$
$\frac{\pi}{10}$
$\frac{10}{7}$

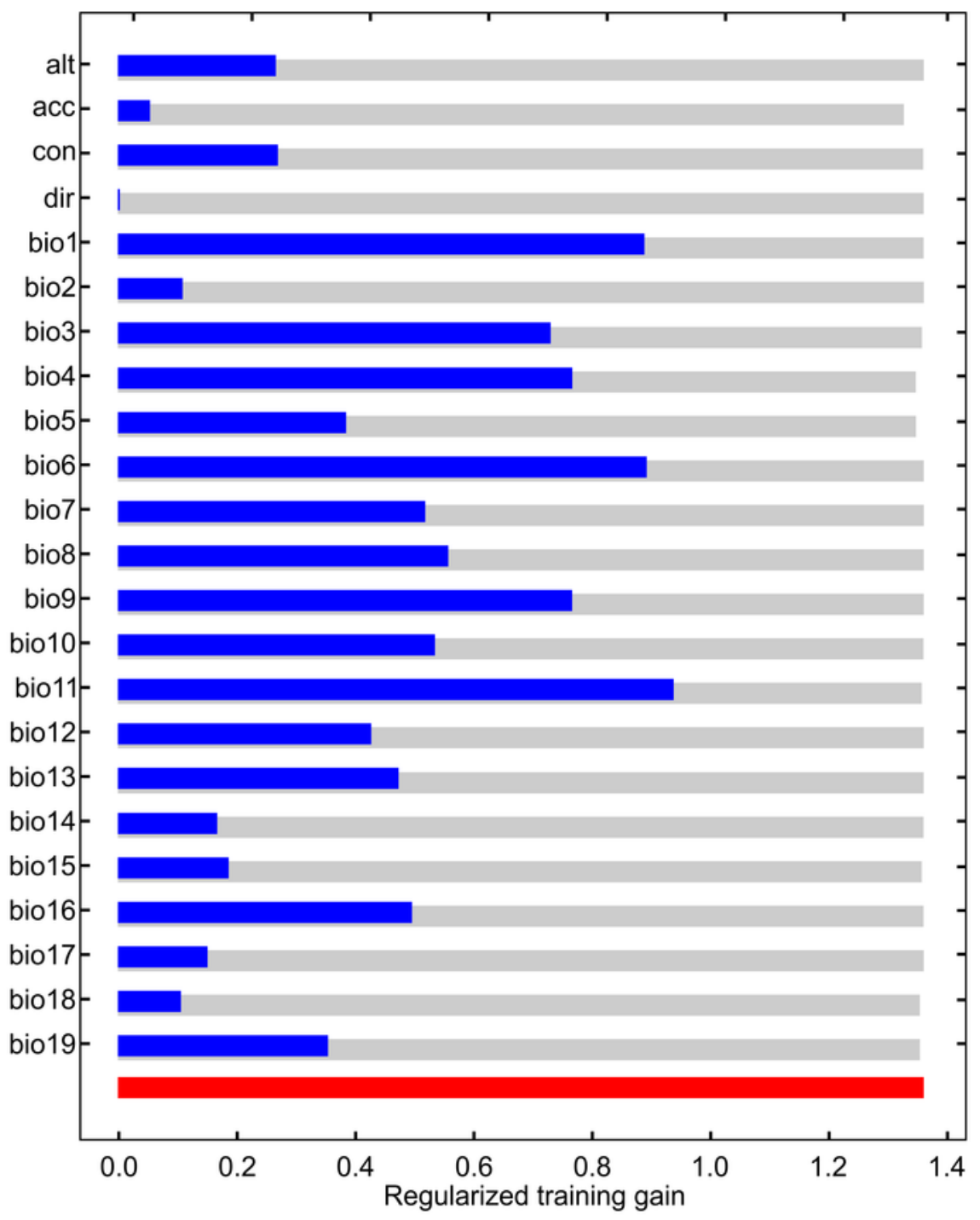

Without variable $\square$
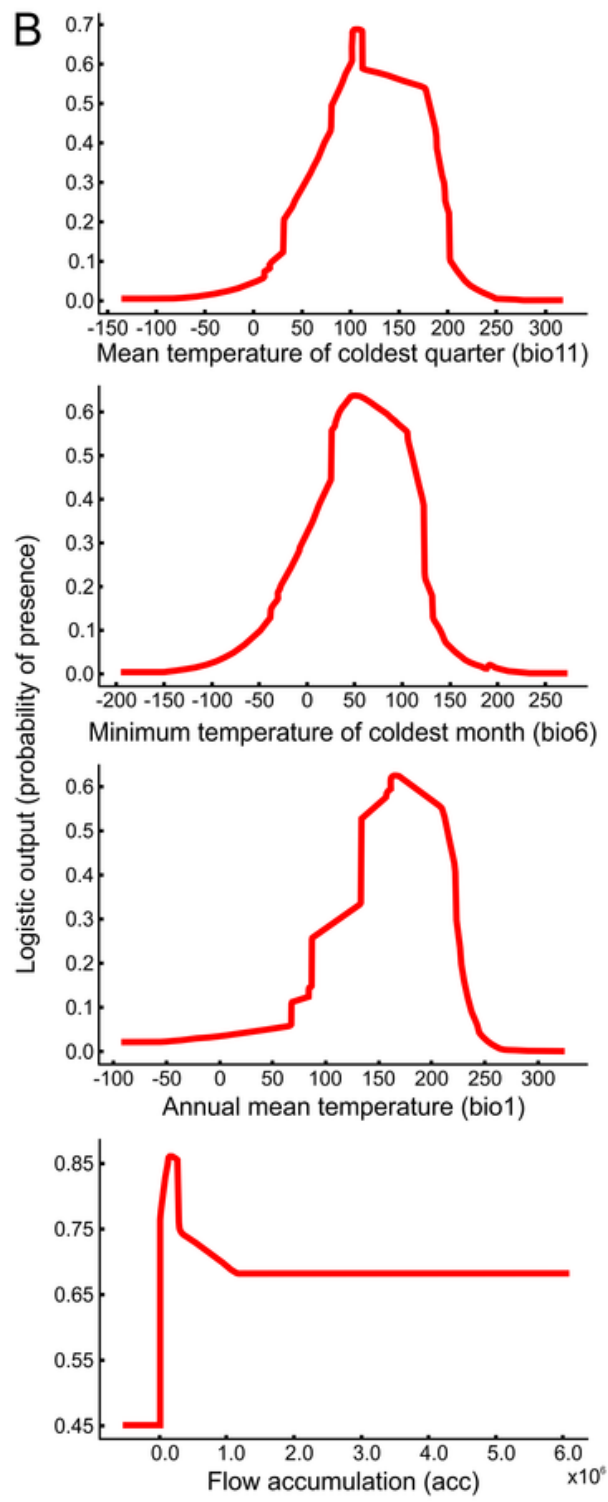


\section{Table $\mathbf{1}$ (on next page)}

Information on the samples used in the phylogenetic reconstruction of Biomphalaria peregrina. 


\begin{tabular}{|c|c|c|c|c|c|}
\hline \multirow[t]{2}{*}{ Sample } & \multirow[t]{2}{*}{ Geographical origin } & \multirow[t]{2}{*}{ Voucher \# } & \multicolumn{2}{|c|}{ GenBank accession \# } & \multirow[t]{2}{*}{ Reference } \\
\hline & & & COI & $16 S-r R N A$ & \\
\hline B. tenagophila** & Mogi das Cruzes, São Paulo, Brazil & LBMSU547 & KF926202 & KF892001 & Tuan et al. (2013)* \\
\hline \multirow{19}{*}{$\begin{array}{l}\text { B. pfeifferi** } \\
\text { B. peregrina }\end{array}$} & Abu Usher, Sudan & - & DQ084835 & DQ084857 & Jørgensen et al. (2007) \\
\hline & Pinturas River, Santa Cruz, Argentina & MLP-Ma14186 & KY124272 & KY124273 & This work \\
\hline & Agua Escondida, Mendoza, Argentina & - & GU168593 & $\begin{array}{l}\text { GU168591 } \\
\text { GU168592 }\end{array}$ & Standley et al. (2011) \\
\hline & La Plata, Buenos Aires, Argentina & UCH La Plata1 & JN621901 & JF309030 & Collado et al. (2011) \\
\hline & & UCH La Plata2 & JN621902 & JF309031 & Collado \& Méndez (2012) \\
\hline & & UCH La Plata3 & JN621903 & JF309032 & \\
\hline & Rancharia, São Paulo, Brazil & LBMSU584 & KF926176 & - & Tuan et al. (2013)* \\
\hline & Bagé, Rio Grande do Sul, Brazil & LBMSU663 & KX354439 & - & Palasio \& Tuan $(2016)^{*}$ \\
\hline & Ipaussu, São Paulo, Brazil & LBMSU761 & KX354440 & - & Palasio \& Tuan (2016)* \\
\hline & & LBMSU756 & KX354441 & - & Palasio \& Tuan (2016)* \\
\hline & & LBMSU755 & KX354442 & - & Palasio \& Tuan (2016)* \\
\hline & & LBMSU338 & - & KF892035 & Tuan \& Palasio (2013)* \\
\hline & Ourinhos, São Paulo, Brazil & LBMSU747 & KX354443 & - & Palasio \& Tuan (2016)* \\
\hline & & LBMSU739 & KX354444 & - & Palasio \& Tuan (2016)* \\
\hline & & LBMSU300 & - & KF892034 & Tuan \& Palasio (2013)* \\
\hline & Martinópolis, São Paulo, Brazil & LBMSU582 & KF926180 & - & Tuan et al. (2013)* \\
\hline & & LBMSU581 & KX354445 & KF892036 & $\begin{array}{l}\text { Palasio \& Tuan }(2016)^{*} \\
\text { Tuan \& Palasio }(2013)^{*}\end{array}$ \\
\hline & Nova Lima, Minas Gerais, Brazil & - & - & AY030232 & DeJong et al. (2001) \\
\hline & San Antonio, Uruguay & - & - & AY030231 & DeJong et al. (2001) \\
\hline
\end{tabular}

$2 *$ GenBank unpublished sequences: the sequence author and submission year are indicated. **Outgroup species. LBMSU,

3 Laboratório de Bioquímica e Biologia Molecular, Superintendência de Controle de Endemias do Estado de São Paulo, Brazil;

4 MLP, Museo de La Plata, Argentina; UCH, Universidad de Chile, Chile. 


\section{Table 2 (on next page)}

Sources of Biomphalaria peregrina occurrences in South America used in the distribution model. 


\begin{tabular}{|c|c|c|}
\hline Country & Occurrences & Sources consulted* \\
\hline Argentina & 343 & $\begin{array}{l}\text { d'Orbigny (1835); Paraense (1966); Bonetto et al. (1990); Castellanos \& Miquel (1991); Rumi } \\
\text { (1991); Rumi et al. (1996); Rumi et al. (1997); Flores \& Brugni (2005); Rumi et al. (2006, 2008); } \\
\text { Ciocco \& Scheibler (2008); Standley et al. (2011) } \\
\text { Malacological collections: CECOAL; IFML; FIOCRUZ; MACN; MLP }\end{array}$ \\
\hline Bolivia & 8 & $\begin{array}{l}\text { Paraense (1966) } \\
\text { Malacological collections: MACN }\end{array}$ \\
\hline Brazil & 241 & $\begin{array}{l}\text { Paraense (1966); Teles et al. (1991); Prando \& Bacha (1995); DeJong et al. (2001); Pepe et al. } \\
\text { (2009) } \\
\text { Malacological collections: FIOCRUZ } \\
\text { Websites: GenBank; WMSDB }\end{array}$ \\
\hline Chile & 24 & $\begin{array}{l}\text { Dunker (1848); Biese (1951); Barbosa et al. (1956) } \\
\text { Malacological collections: FIOCRUZ; MACN }\end{array}$ \\
\hline Colombia & 1 & Website: WMSDB \\
\hline Ecuador & 12 & $\begin{array}{l}\text { d'Orbigny (1835); Cousin (1887); Paraense }(1966,2004) \\
\text { Malacological collections: FIOCRUZ } \\
\text { Website: WMSDB }\end{array}$ \\
\hline Paraguay & 29 & $\begin{array}{l}\text { In Quintana (1982): Paravicini (1894); Bertoni (1925); Schade (1965); Russell (1972); Moreno } \\
\text { González (1981) } \\
\text { Malacological collections: MACN }\end{array}$ \\
\hline Peru & 6 & $\begin{array}{l}\text { Paraense (2003) } \\
\text { Malacological collections: FIOCRUZ } \\
\text { Website: WMSDB }\end{array}$ \\
\hline Uruguay & 23 & $\begin{array}{l}\text { Paraense (1966); DeJong et al. (2001); Scarabino (2004) } \\
\text { Malacological collections: FIOCRUZ; MACN } \\
\text { Website: GanBank; WMSDB }\end{array}$ \\
\hline Venezuela & 2 & Website: WMSDB \\
\hline \multicolumn{3}{|c|}{ *CECOAL, Centro de Ecología Aplicada del Litoral; FIOCRUZ, Fundação Oswaldo Cruz; IFML, Instituto Fundación Miguel } \\
\hline \multicolumn{3}{|c|}{ Lillo; MACN, Museo Argentino de Ciencias Naturales; MLP, Museo de La Plata; WMSDB, Worldwide Mollusc Species Data } \\
\hline Base & & \\
\hline
\end{tabular}




\section{Table 3(on next page)}

Variables used in the model development. Temperatures are expressed in ${ }^{\circ} \mathrm{C} * 10$, precipitations in $\mathrm{mm}$, elevation above sea level in $\mathrm{m}$, and flow accumulation in number of cells. 


\begin{tabular}{ll}
\hline Variable & Description \\
\hline alt & Altitude \\
bio1 & Annual mean temperature \\
bio2 & Mean diurnal range (monthly mean, $\mathrm{T}^{\circ}$ max- $\mathrm{T}^{\circ}$ min) \\
bio3 & Isothermality (bio2/bio7) x 100 \\
bio4 & Temperature seasonality (standard deviation x 100) \\
bio5 & Maximum temperature of warmest month \\
bio6 & Minimum temperature of coldest month \\
bio7 & Temperature annual range (bio5-bio6) \\
bio8 & Mean temperature of wettest quarter \\
bio9 & Mean temperature of driest quarter \\
bio10 & Mean temperature of the warmest quarter \\
bio11 & Mean temperature of coldest quarter \\
bio12 & Annual precipitation \\
bio13 & Precipitation of wettest month \\
bio14 & Precipitation of driest month \\
bio15 & Precipitation seasonality (coefficient of variation) \\
bio16 & Precipitation of wettest quarter \\
bio17 & Precipitation of driest quarter \\
bio18 & Precipitation of the warmest quarter \\
bio19 & Precipitation of the coldest quarter \\
acc & Flow accumulation \\
dir & Flow direction \\
con & Hydrologically conditioned elevation \\
\hline
\end{tabular}

1 


\section{Table 4 (on next page)}

Genetic distances among COI haplotypes of Biomphalaria peregrina.

The distances are listed as uncorrected (below the diagonal) and corrected by the Kimura's two parameter substitution model (above the diagonal). 


\begin{tabular}{llllllll}
\hline & $\mathrm{H}_{1}$ & $\mathrm{H}_{2}$ & $\mathrm{H}_{3}$ & $\mathrm{H}_{4}$ & $\mathrm{H}_{5}$ & $\mathrm{H}_{6}$ & GenBank accession numbers* \\
\hline $\mathrm{H}_{1}$ & - & 0.012987 & 0.012987 & 0.026321 & 0.030198 & 0.028256 & $\mathrm{H}_{1}:$ KF926176; KF926180; KX354445 \\
$\mathrm{H}_{2}$ & 0.012820 & - & 0.011116 & 0.032147 & 0.036068 & 0.034104 & $\mathrm{H}_{2}: \mathrm{KX} 354441$ \\
$\mathrm{H}_{3}$ & 0.012820 & 0.010989 & - & 0.032147 & 0.036068 & 0.034104 & $\mathrm{H}_{3}: \mathrm{KX} 354440 ; \mathrm{KX} 354442 ; \mathrm{KX} 354443 ; \mathrm{KX} 354444$ \\
$\mathrm{H}_{4}$ & 0.025641 & 0.031135 & 0.031135 & - & 0.003676 & 0.001834 & $\mathrm{H}_{4}: \mathrm{KY} 124272 ; \mathrm{GU} 168593$ \\
$\mathrm{H}_{5}$ & 0.029304 & 0.034798 & 0.034798 & 0.003663 & - & 0.005525 & $\mathrm{H}_{5}: \mathrm{KX} 354439$ \\
$\mathrm{H}_{6}$ & 0.027472 & 0.032967 & 0.032967 & 0.001831 & 0.005494 & - & $\mathrm{H}_{6}:$ JN621901; JN621902; JN621903 \\
\hline
\end{tabular}

1

$2 *$ References to the sequences are provided in Table 1. 